\title{
Emulsi Sereh Wangi untuk Konservasi Cagar Budaya Berbahan Batu dan Bata
}

\author{
Sri Wahyuni, A.Md', Zulfah Laili, S.Si², Al Widyo Purwoko ${ }^{3}$ \\ Balai Konservasi Borobudur \\ nyun2_euro@yahoo.com
}

\begin{abstract}
ABSTRAK
Emulsi sereh wangi diuji sebagai bahan alternatif ramah lingkungan untuk membunuh koloni lumut dan lumut kerak/lichen pada cagar budaya berbahan batu dan bata. Bahan uji terdiri dari minyak atsiri sereh wangi dan surfaktan tween 80 . Variasi konsentrasi emulsi sereh wangi yaitu 3\%, 5\%, 7\% dan $10 \%$ dengan konsentrasi surfaktan tween 80, 5\%. Pengujian bahan skala lapangan dengan cara penyemprotan pada obyek yang ditumbuhi koloni lumut dan lumut kerak.

Emulsi sereh wangi konsentrasi minimal 3\% dapat membunuh lumut setelah kontak selama 24 jam dan konsentrasi minimal 5\% dapat membunuh lumut kerak setelah kontak selama 48 jam, dilihat dari perubahan warna hijau menjadi kecoklatan dan mengering. Perubahan warna lumut setelah kontak 24 jam konsentrasi maksimal pengujian 10\%, dilihat nilai $\Delta \mathrm{E} 2000$ sebesar 8,5721 dan perubahan warna lumut kerak setelah kontak 48 jam sebesar 7,2063. Emulsi sereh wangi tidak berdampak merubah warna batu segar(bersih), pengukuran $\Delta \mathrm{E} 2000$ setelah 6 hari perlakuan sebesar 3,4592 .
\end{abstract}

Kata Kunci: Konservasi, lumut, lichen, emulsi sereh wangi

\section{ABSTRACT}

Citronella emulsion was tested as an environmentally friendly alternative material to kill moss and lichen colonies on cultural heritage made of stone and brick. Emulsion was prepared by mixing citronella essential oil and surfactant tween 80. The concentration variations which had tested as follows: $3 \%, 5 \%, 7 \%$, and $10 \%$ with a concentration of tween 80 surfactant in water of 5\%. Testing of field-scale materials by spraying on objects overgrown with moss and lichen colonies.

Citronella emulsion with a minimum concentration of $3 \%$ can kill moss after contact for 24 hours and a minimum concentration of $5 \%$ can kill lichen after contact for 48 hours, seen from the change in colour from green to brown and dry. Moss color change after 24 hours of contact with a maximum concentration of $10 \%$ as seen from the E2000 value of 8.5721 and the color change of lichen after 48 hours of contact was 7.2063. Citronella emulsion did not have an impact on changing the color of the rock on fresh stone, the measurement after 6 days of treatment was 3.4592 .

Keywords: Conservation, moss, lichen, Citronella emulsion 


\section{PENDAHULUAN}

Cagar budaya berbahan batu sangat rentan terhadap kerusakan dan pelapukan baik yang diletakkan di dalam ruangan maupun di luar ruangan. Jenis kerusakan dan pelapukan terdiri dari fisis, kimia dan biologi. Pelapukan yang terjadi pada cagar budaya berbahan batu akibat dari faktor biologi disebabkan oleh pertumbuhan ganggang/algae, lumut/moss, lumut kerak/lichen.

Pelapukan batu oleh lumut (Musci dan Hepaticae) disebabkan oleh mekanisme biogeokimia dan biogeofisika (Altieri, A and Ricci, S. 1997). Lumut memiliki kemampuan untuk melakukan penetrasi ke semua tipe batuan dengan rhizoidnya. Lumut juga memiliki kemampuan dalam mengakumulasi ion kalsium dari subtratnya. Karena keasaman yang lebih tinggi pada rhizoidnya, organisme ini memiliki kemampuan yang tinggi untuk mengekstraksi kation mineral batu (Kumar, R and Kumar, A.V. ;1999).

Lichen merupakan organisme gabungan antara jamur dan alga. Peran lichen dalam proses kerusakan dan pelapukan batu dapat secara mekanik dan kimiawi. Kembang susut talus lichen, penempelan rhizines, dan penetrasi hifa pada batuan merupakan peran lichen secara mekanik. Sedangkan secara kimiawi, lichen dapat berinteraksi dengan karbondioksida dan menghasilkan metabolit yang bersifat asam serta kelat (chelating agent) (De los Rios \& Ascaso, 2005). Talus lichen epilitik berkembang di permukaan batu, tetapi hifa dapat melakukan penetrasi ke dalam struktur batuan. Kemampuan lichen untuk merubah substratnya tergantung pada perbedaan fisiologis diantara spesies lichen dan sifat, tekstur dan struktur substrat (De Los Rios et al., 2012). Lichen bentuk crustose dapat menempel dengan kuat pada batuan. Talus lichen dapat menguraikan berbagai macam mineral (kalsit, quartz, feldspar, micas, dan lain lain) pada batuan intermediate dengan ditandai adanya korosi pada permukaan batu.

Upaya mengatasi penyebab kerusakan dan pelapukan yang disebabkan oleh pertumbuhan lumut selama ini dengan pembersihan secara mekanis kering, mekanis basah dan bahan kimia Sedangkan untuk mengatasi lumut kerak/lichen selama ini menggunakan bahan kimia AC 322. Komponen AC 322 sendiri terdiri dari ammonium bikarbonat, sodium bikarbonat, disodium salt EDTA, CMC, Arkopal dan air. Penanganan lumut dengan pembersihan secara mekanis kering dan basah tidak mengatasi pertumbuhan lumut karena bersifat hanya memindahkan spora dan tidak membunuh lumut. Sedangkan penggunaan bahan kimia seperti $A C 322$ dan herbisida dapat mencemari lingkungan.

Bahan AC 322 selama ini merupakan satu-satunya bahan yang digunakan dalam menangani permasalahan lumut kerak pada cagar budaya berbahan batu dan bata. Oleh 
sebab itu upaya pengembangan bahan konservan sebagai alternatif lain untuk penanganan permasalahan lumut kerak perlu dipikirkan.

Minyak atsiri banyak tersedia di alam dan berbagai macam minyak atsiri sudah banyak digunakan sebagai bahan antijamur. Penelitian yang dilakukan oleh Wahyuni dkk. (2015), penggunaan minyak atsiri untuk menghambat pertumbuhan jamur Penicillium $s p$ dari lumut kerak pada cagar budaya batu andesit dengan menggunakan minyak atsiri nilam, minyak temulawak, dan minyak terpentin. Dari beberapa jenis minyak atsiri yang digunakan minyak atsiri cengkeh, biji pala, nilam, temulawak dan terpentin mampu menghambat pertumbuhan jamur Penicillium sp dari lumut kerak. Penghambatan terhadap jamur Penicillium sp secara berturut-turut adalah nilam > temulawak > cengkeh > pala.

Penelitian lanjutan yang dilakukan oleh Wahyuni dkk. (2016), untuk mengetahui daya hambat minyak atsiri terhadap pertumbuhan alga pada lumut kerak. Minyak atsiri yang digunakan adalah minyak atsiri cengkeh, biji pala, temulawak dan nilam. Dari hasil kajian diperoleh kesimpulan minyak atsiri nilam, temulawak, cengkeh dan pala berdasarkan percobaan dapat menghambat pertumbuhan sel mikroalga dari lumut kerak. Penghambatan terhadap mikroalga secara berturut-turut adalah temulawak > pala > nilam > cengkeh.

Penelitian untuk mengatasi permasalahan mikroorganisme seperti lumut dan lumut kerak/lichen pada cagar budaya berbahan batu dan bata terus dikembangkan khususnya bahan alam berupa minyak atsiri. Penelitian ini dengan menggunakan minyak atsiri sereh wangi. Sereh wangi menurut Ketaren(1985) mengandung sitronelal berkisar antara 32-45\%, geraniol 12-18\% dan sitronelol 12-15\%. Penelitain Emulsi sereh wangi terdiri dari minyak atsiri sereh wangi dan surfaktan tween 80 .

Adapun tujuan dari penelitian ini adalah mengetahui efektifitas emulsi minyak atsiri sereh wangi dan konsentrasi minimal untuk membunuh koloni lumut dan lumut kerak /lichen pada cagar budaya berbahan batu dan bata

\section{METODE}

\section{Alat dan Bahan}

Alat yang digunakan antara lain sprayer, gelas ukur, gelas beker, corong, batang pengaduk, kolorimeter dan aplikasi dengan software colortool

Bahan yang digunakan dalam penelitian ini adalah minyak atsiri sereh wangi, surfaktan tween 80 dan akuades. 


\section{Metode Pengumpulan Data}

Metode pengumpulan data yang digunakan dalam kajian ini meliputi pengujian skala lapangan. Adapun tahapan penelitian selengkapnya adalah sebagai berikut:

1. Pembuatan emulsi sereh wangi

Menyiapkan minyak atsiri sereh wangi 3\%, 5\%,7\%, dan 10\% dalam pelarut air dengan surfatan tween 80 .

- Larutan Tween 80 konsentrasi 5\%

Untuk membuat $1000 \mathrm{ml}$ larutan tween 5\%, maka ditakar sebanyak $50 \mathrm{ml}$ tween 80 dan dimasukkan ke dalam labu takar 1000 ml, lalu dilarutkan dengan akuades hingga volume total $1000 \mathrm{ml}$.

- Emulsi sereh wangi 3\%, 5\%, 7\% dan 10\%

Untuk membuat $1000 \mathrm{ml}$ emulsi sereh wangi konsentrasi 3\%, 5\%, 7\% dan 10\%, maka ditakar masing-masing sebanyak $30 \mathrm{ml}, 50 \mathrm{ml}, 70 \mathrm{ml}$ dan $100 \mathrm{ml}$ minyak atsiri sereh wangi dan dimasukkan masing-masing ke dalam labu takar $1000 \mathrm{ml}$, lalu dilarutkan dengan akuades hingga volume total $1000 \mathrm{ml}$.

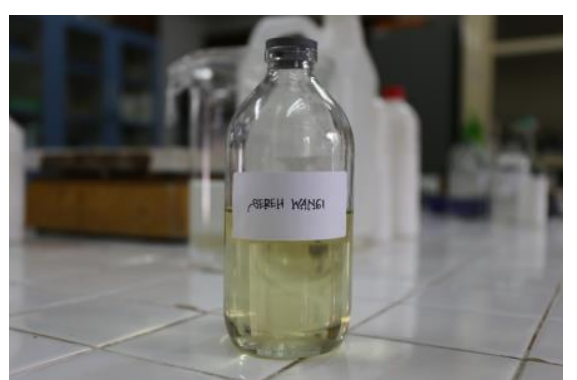

Gambar 1. Minyak Atsiri Sereh Wangi (Sumber: Balai Konservasi Borobudur, 2021)

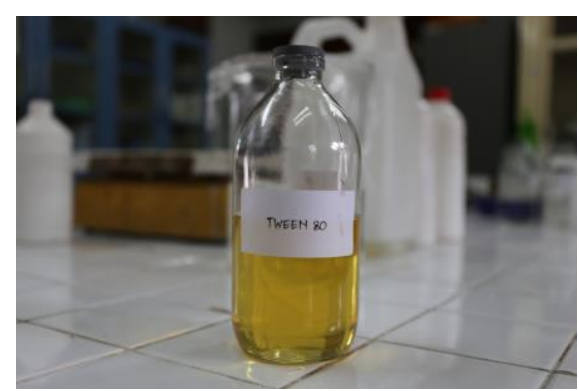

Gambar 2. Surfaktan Tween 80 (Sumber: Balai Konservasi Borobudur, 2021)

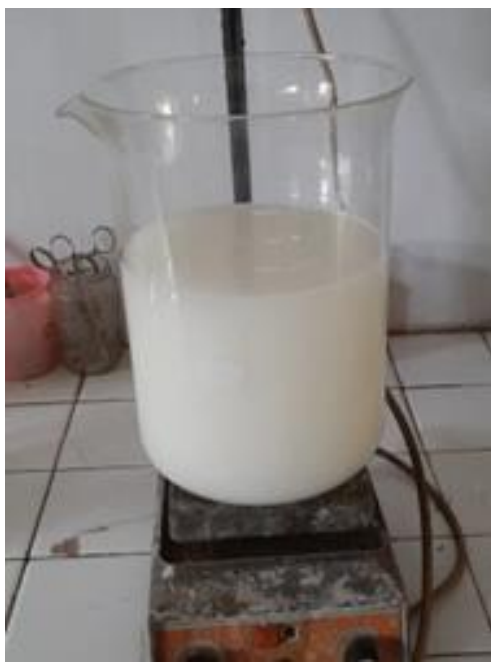

Gambar 3. Emulsi Sereh Wangi (Sumber: Dokumen Pribadi, 2021)

2. Pengujian Lapangan

Pengujian di lapangan di aplikasikan pada permukaan batu yang ditumbuhi lumut dan lumut kerak. Pengujian dengan menggunakan variasi konsentrasi yang diujikan 
meliputi $3 \%, 5 \%$, 7\%, dan 10\%. Sebagai kontrol berupa lumut dan lumut kerak pada batu yang tidak diberi perlakuan. Pengaplikasian minyak atsiri pada permukaan batu yang ditumbuhi lumut dan lumut kerak dengan cara penyemprotan hingga jenuh. Pengujian lapangan dilakukan terhadap 3 blok batu untuk 3 kali ulang, masing-masing blok batu dibagi menjadi 5 bagian yaitu 1 bagian blok untuk kontrol, dan 4 bagian blok untuk pengujian minyak atsiri sereh wangi masing-masing dengan konsentrasi $3 \%, 5 \%, 7 \%$ dan $10 \%$. Metode penyemprotan dipilih untuk memudahkan dalam pengaplikasian dan larutan yang digunakan lebih efisien dibandingkan dengan cara pengolesan, dapat dilihat pada Gambar 4. Pengamatan dilakukan sebelum pengaplikasian dan setelah pengaplikasian. Pengamatan perubahan warna dilakukan 24 jam dan 48 jam setelah dilakukan penyemprotan emulsi sereh wangi.

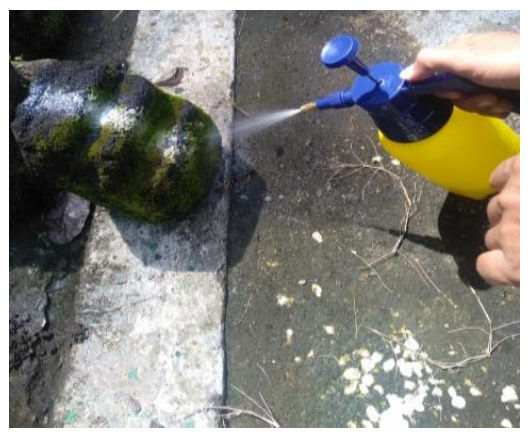

Gambar 4. Pengaplikasian emulsi sereh wangi dengan cara penyemprotan (Sumber: Balai Konservasi Borobudur, 2021)

3. Pengolahan data

Data terdiri dari kualitatif dan kuantitatif. Data kualitatif berupa pengamatan secara visual perubahan warna koloni lumut dan lumut kerak/lichen. Sedangkan data kualitatif berupa data perubahan warna nilai $\Delta \mathrm{E} 2000$.

Pengukuran skala warna menggunakan kolorimeter diperoleh data nilai LAB kemudian dihitung nilai $\Delta \mathrm{E}$ pada aplikasi dengan software colortool. Setiap percobaan dilakukan pengukuran nilai LAB sebanyak 5 kali pengulangan kemudian dirata-rata. Alat kolori meter dan soft ware colortool ditampilkan dalam Gambar 5.

Nilai $\Delta \mathrm{E}$ menunjukkan skala perubahan warna pada lumut dan lumut kerak/lichen setelah pengaplikasian minyak atsiri dengan berbagai macam variasi konsentrasi. 


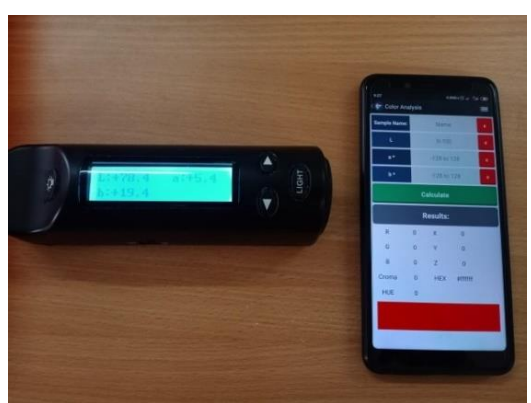

Gambar 5. Angka yang terbaca pada alat kolorimeter dikomparasi dengan software Color Tools (Sumber: Balai Konservasi Borobudur, 2021)

\section{HASIL PENELITIAN DAN PEMBAHASAN}

Konsentrasi minyak atsiri sereh wangi yang digunakan dalam penelitian ini sebanyak 4 variasi yaitu $3 \%, 5 \%, 7 \%$ dan $10 \%$. Hal ini bertujuan untuk mencari konsentrasi optimum yang dapat digunakan untuk membunuh lumut dan lumut kerak/lichen. Penggunaan tween 80 konsnetrasi $5 \%$ sebagai surfaktan digunakan untuk menurunkan tegangan antar muka antara minyak dengan air sehingga dapat mudah bercampur membentuk emulsi.

\section{Pengamatan Visual dan Mikroskopis}

Pengamatan secara visual dilakukan secara langsung dan kemudian didokumentasikan dengan kamera sedangkan pengamatan secara mikroskopis menggunakan mikroskop. Pengamatan secara visual dan mikroskopis bertujuan untuk mengetahui penampang lumut dan lumut kerak/lichen sebelum dan setelah diberi perlakuan dengan emulsi sereh wangi.

a. Lumut pada permukaan Batu

Hasil pengamatan lumut secara visual ditampilkan pada Tabel 1.

Tabel 1. Pengamatan lumut secara Visual

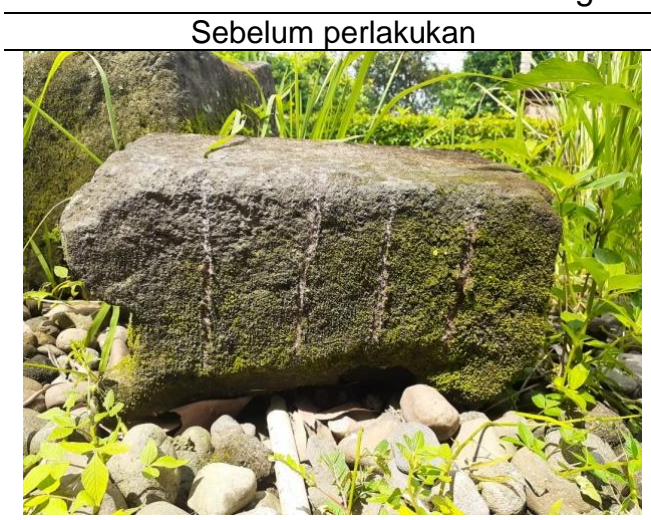

Semua koloni lumut tampak berwarna hijau segar

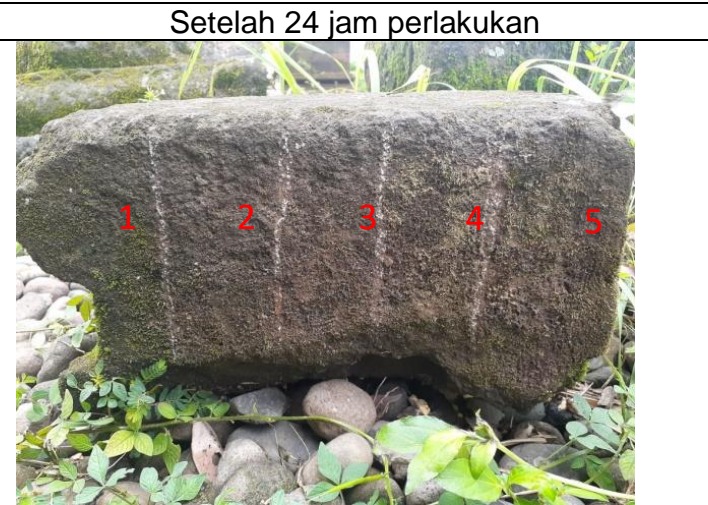

- Koloni lumut pada kontrol (1 dari kanan) masih berwarna hijau segar

- Koloni lumut pada perlakukan menggunakan minyak atsiri sereh wangi konsentrasi $3 \%$ (nomor 2) sudah menunjukkan perubahan warna menjadi coklat.

(Sumber : Dokumen Pribadi, 2021) 
Hasil pengamatan lumut secara mikroskopis ditampilkan pada Tabel.2.

Tabel 2. Pengamatan lumut secara mikroskopis

\begin{tabular}{|c|c|c|c|}
\hline $\begin{array}{c}\text { Konsen } \\
\text { trasi }\end{array}$ & Sebelum perlakukan & Setelah 24 jam perlakukan & Keterangan \\
\hline Kontrol & & & $\begin{array}{l}\text { Koloni lumut } \\
\text { tanpa perlakuan } \\
\text { menunjukkan } \\
\text { warna hijau segar }\end{array}$ \\
\hline $3 \%$ & & & $\begin{array}{l}\text { Koloni lumut } \\
\text { sebelum dan } \\
\text { setelah perlakuan } \\
\text { menunjukkan } \\
\text { perubahan warna } \\
\text { dari hijau menjadi } \\
\text { coklat dan layu }\end{array}$ \\
\hline $5 \%$ & & & $\begin{array}{l}\text { Koloni lumut } \\
\text { sebelum dan } \\
\text { setelah perlakuan } \\
\text { menunjukkan } \\
\text { perubahan warna } \\
\text { dari hijau menjadi } \\
\text { coklat dan layu }\end{array}$ \\
\hline $7 \%$ & & $\frac{3}{6}$ & $\begin{array}{l}\text { Koloni lumut } \\
\text { sebelum dan } \\
\text { setelah perlakuan } \\
\text { menunjukkan } \\
\text { perubahan warna } \\
\text { dari hijau menjadi } \\
\text { coklat dan layu }\end{array}$ \\
\hline $10 \%$ & & & $\begin{array}{l}\text { Koloni lumut } \\
\text { sebelum dan } \\
\text { setelah perlakuan } \\
\text { menunjukkan } \\
\text { perubahan warna } \\
\text { dari hijau menjadi } \\
\text { coklat dan layu }\end{array}$ \\
\hline
\end{tabular}

(Sumber : Dokumen Pribadi, 2021)

Kondisi lumut pada batu sebelum perlakuan, semua koloni lumut berwarna hijau segar sedangkan setelah perlakuan menggunakan minyak atsiri sereh wangi variasi konsentrasi $3 \%$, 5\%, 7\% dan 10\% dalam durasi waktu 24 jam kondisi lumut sudah menunjukkan perubahan warna menjadi coklat, perubahan secara visual dapat dilihat pada Tabel 1. Pengamatan kematian lumut diperjelas dengan pengamatan secara mikroskopis di tampilkan pada Tabel 2. Terlihat bahwa lumut setelah perlakuan menggunakan minyak 
atsiri sereh wangi mengalami perubahan warna menjadi coklat, dalam keadaan kering dan layu. Hal ini menandakan bahwa lumut telah mati karena telah kehilangan zat hijau daun/ klorofil sehingga tidak dapat melakukan proses fotosintesis.

b. Lumut kerak/Lichen pada permukaan Batu

Tabel. 3 menampilkan pengamatan lumut kerak/lichen pada permukaan batu secara visual.

Tabel 3. Pengamatan lumut kerak/lichen batu secara visual

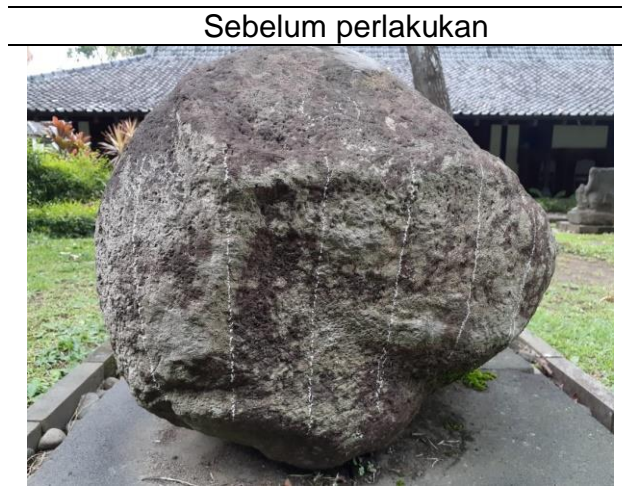

Koloni lumut kerak/lichen tampak berwarna putih agak kehijauan

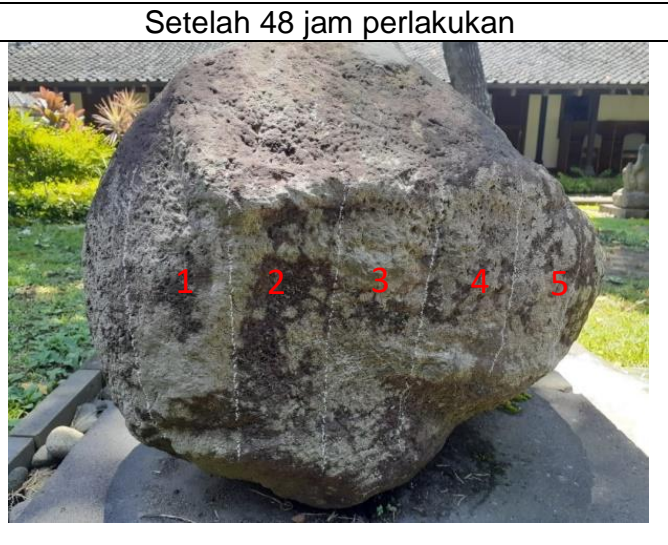

Koloni lumut kerak/lichen kontrol dan perlakuan konsentrasi 3\%(no 1 dan 2) tampak masih sama sedangkan konsentrasi $5 \%, 7 \%, 10 \%$ (no 3, 4 dan 5) tampak berubah menjadi putih kecoklatan.

(Sumber : Dokumen Pribadi, 2021)

Penyemprotan lumut kerak/lichen menggunakan emulsi sereh wangi berbagai konsentrasi $3 \%, 5 \%, 7 \%$ dan $10 \%$ selama 48 jam menunjukkan terjadi perubahan warna dari putih menjadi putih kecoklatan pada konsentrasi 5\%, 7\% dan 10\% sedangkan konsemtrasi 3\% masih sama dengan kontrol tidak menunjukkan perubahan warna. Adanya perubahan warna menunjukkan bahwa emulsi sereh wangi dapat membunuh lumut kerak/lichen pada batuan.

Hasil pengamatan lumut kerak/lichen secara mikroskopis ditampilkan pada Tabel.4.

Tabel 4. Pengamatan lumut kerak/lichen secara mikroskopis

\begin{tabular}{|c|c|c|c|}
\hline $\begin{array}{c}\text { Konsen } \\
\text { trasi }\end{array}$ & Sebelum perlakukan & Setelah 48 jam perlakukan & Keterangan \\
\hline Kontrol & & $\frac{x^{2}+x^{4}}{2 x^{2}}$ & $\begin{array}{l}\text { Lumut } \\
\text { kerak/lichen tanpa } \\
\text { perlakuan tampak } \\
\text { berwana putih } \\
\text { kecoklatan dan } \\
\text { sedikit berwana } \\
\text { hijau }\end{array}$ \\
\hline $3 \%$ & & & $\begin{array}{l}\text { Lumut } \\
\text { kerak/lichen } \\
\text { sebelum dan } \\
\text { setelah perlakuan } \\
\text { tidak } \\
\text { menunjukkan } \\
\text { perubahan warna, }\end{array}$ \\
\hline
\end{tabular}


Kondisi lumut kerak/lichen pada batu sebelum perlakuan, semua koloni lumut kerak/lichen berwarna hijau kecoklatan, ditampilkan pada Tabel 3. Emulsi sereh wangi konsentrasi $3 \%$ tidak menunjukkan adanya perubahan warna pada lichen baik secara visual dapat dilihat pada Tabel 3, diperkuat dengan penampakan secara mikroskopis dilahat pada Tabel 4. Perubahan warna lumut kerak/lichen setelah perlakuan terjadi pada perlakuan emulsi sereh wangi konsentrasi 5\%, 7\% dan 10\% durasi kontak selama 48 jam. Kondisi lumut kerak/lichen sudah menunjukkan perubahan warna dari hijau kecoklatan menjadi coklat dan kering.

\section{Perhitungan Perubahan Warna}

Pengukuran perubahan warna berdasarkan pada perubahan nilai LAB sebelum dan setelah perlakuan dengan menggunakan alat kolorimeter. Berdasarkan jurnal CIELab oleh Hunterlab Association Laboratory (2008), dapat ditunjukkan, dimana $\mathrm{L}^{*}$ menunjukkan light/terang, $\mathrm{a}^{*}$ menunjukkan koordinat merah/hijau dan $\mathrm{b}^{*}$ menunjukkan koordinat kuning/biru. Tahap selanjutkan nilai Lab dimasukkan dalam software colortools.

Berdasarkan National Bureau of Standards GB7705-87 (National Institute of Standards and Technology), suatu benda dikatakan memiliki warna yang sama jika memiliki nilai $\Delta \mathrm{E}$ $\leq 6$.

\section{a. Lumut}

Pengukuran perubahan warna pada lumut dilakukan sebelum dan setelah perlakuan 24 jam. Pengukuran dilakukan sebanyak 5 kali dengan mengukur warna LAB menggunakan alat kolorimeter.

Tabel 5. Nilai $\Delta \mathrm{E}$ lumut pada batu pengujian emulsi sereh wangi $3 \%$

\begin{tabular}{|c|c|c|c|c|c|c|c|c|c|c|c|c|c|}
\hline \multirow{3}{*}{$\begin{array}{c}\text { Bahan SW } \\
3 \%\end{array}$} & \multicolumn{9}{|c|}{ Nilai Kolorimeter rata-rata 5 kali pengulangan Batu 1,2, 3} & \multirow{2}{*}{\multicolumn{4}{|c|}{$\Delta \mathrm{E} 2000$}} \\
\hline & & $L^{*}$ & & & A & & & B & & & & & \\
\hline & B1 & B2 & B3 & B1 & B2 & B3 & B1 & B2 & B3 & $\mathrm{B} 1$ & B2 & B3 & $\begin{array}{l}\text { Rata- } \\
\text { Rata }\end{array}$ \\
\hline \multirow{2}{*}{$\begin{array}{l}\text { Sebelum } \\
\text { Setelah } 24 \\
\text { jam } \\
\text { Perlakuan }\end{array}$} & 30,2 & 24,0 & 26,1 & 0,2 & 1,5 & 0,3 & 17,2 & 19,8 & 12,9 & \multirow{2}{*}{$\begin{array}{c}6,24 \\
45\end{array}$} & \multirow{2}{*}{$\begin{array}{c}8,84 \\
39\end{array}$} & \multirow{2}{*}{6,976} & \multirow{2}{*}{$\begin{array}{c}7,35 \\
48\end{array}$} \\
\hline & 25,6 & 25,9 & 26,4 & 3,2 & 4,4 & 5,1 & 12,9 & 12,4 & 9,6 & & & & \\
\hline
\end{tabular}

Nilai $\Delta$ E2000 rata-rata pada ketiga batu uji, konsentrasi emulsi sereh wangi $3 \%$ sudah menunjukkan adanya perbedaan warna, hal ini dapat dilihat pada Tabel 5 , nilai $\Delta \mathrm{E} 2000$ sebesar 7,3548 yang nilainya lebih dari 6. Berdasarkan National Bureau of Standards GB7705-87 (National Institute of Standards and Technology), suatu benda dikatakan memiliki warna yang sama jika memiliki nilai $\Delta \mathrm{E} \leq 6$. 
Untuk mengetahui perubahan warna lumut berdasarkan nilai $\Delta \mathrm{E}$ berdasarkan variasi konsentrasi emulsi sereh wangi 3\%, 5\%, 7\% dan 10\%, maka disajikan dalam Grafik 1.

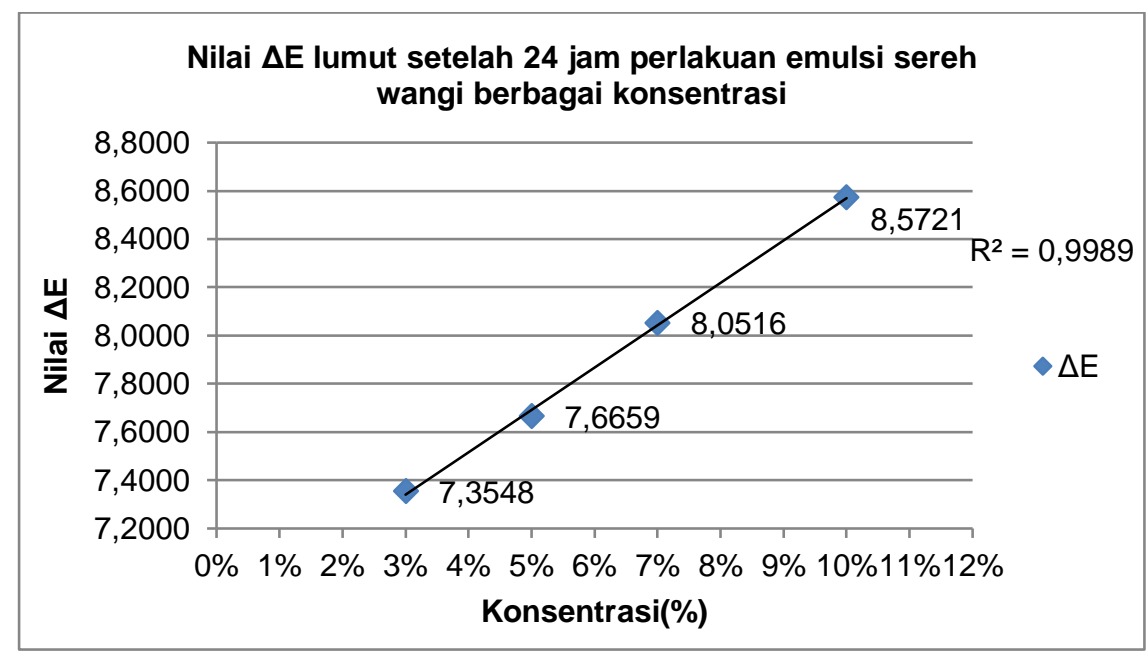

Grafik 1. Nilai $\Delta \mathrm{E} 2000$ lumut setelah 24 jam perlakuan

Berdasarkan Grafik 1 menunjukkan bahwa semakin tinggi konsentrasi maka terjadi kenaikan nilai $\Delta \mathrm{E} 2000$, hal ini menandakan bahwa semakin besar konsentrasi terjadi semakin terjadi perbedaan perubahan warna. Konsentrasi emulsi sereh wangi $3 \%$ sudah dapat merubah warna lumut dari hijau menjadi kecoklatan sesuai dengan pengamatan visual dan mikroskopis.

\section{b. Lumut Kerak/Lichen}

Pengukuran perubahan warna pada lumut kerak dilakukan sebelum dan setelah perlakuan 48 jam. Pengukuran dilakukan sebanyak 5 kali dengan mengukur warna Lab menggunakan alat kolorimeter.

Tabel 6. Nilai $\Delta \mathrm{E} 2000$, lichen pada batu pengujian emulsi sereh wangi $5 \%$

\begin{tabular}{|c|c|c|c|c|c|c|c|c|c|c|c|c|c|}
\hline \multirow{3}{*}{$\begin{array}{l}\text { Bahan } \\
\text { SW 5\% }\end{array}$} & \multicolumn{9}{|c|}{$\begin{array}{c}\text { Nilai Kolorimeter rata-rata } 5 \text { kali pengulangan Batu 1,2, } \\
3\end{array}$} & \multirow{2}{*}{\multicolumn{4}{|c|}{$\Delta \mathrm{E} 2000$}} \\
\hline & & $\mathrm{L}$ & & & $A$ & & & B & & & & & \\
\hline & B1 & B2 & B3 & B1 & B2 & B3 & B1 & B2 & B3 & B1 & B2 & B3 & $\begin{array}{l}\text { Rata- } \\
\text { Rata }\end{array}$ \\
\hline Sebelum & & & & & - & & & & & & & & \\
\hline Setelah & 41,5 & 36,4 & 32,7 & 0,7 & 0,2 & 1,2 & 9,7 & 8,4 & 9,7 & 9,98 & 2,69 & 7,61 & 6,76 \\
\hline $\begin{array}{l}48 \text { jam } \\
\text { Perlakuan }\end{array}$ & 32,2 & 37,5 & 24,5 & 4,3 & 1,5 & 2,8 & 5,6 & 10,0 & 5,2 & 47 & 66 & 54 & 56 \\
\hline
\end{tabular}


Nilai $\Delta$ E2000 rata-rata pada ketiga batu uji, konsentrasi emulsi sereh wangi 5\% sudah menunjukkan adanya perbedaan warna, hal ini dari nilai $\Delta \mathrm{E} 2000$ sebesar 6,7656 yang nilainya lebih dari 6 . Suatu benda dikatakan memiliki warna yang sama jika memiliki nilai $\Delta \mathrm{E} \leq 6$.

Untuk mengetahui perubahan warna lumut kerak/lichen berdasarkan nilai $\Delta \mathrm{E}$ berdasarkan variasi konsentrasi emulsi sereh wangi $3 \%, 5 \%, 7 \%$ dan 10\%, maka disajikan dalam grafik di bawah ini :

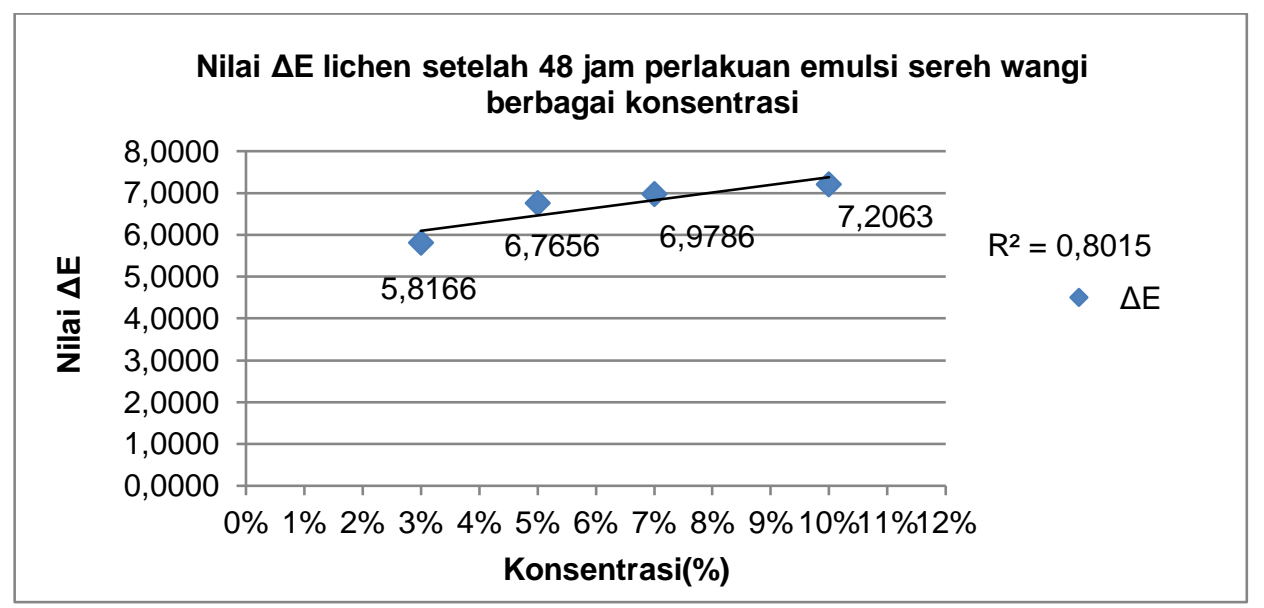

Grafik 2. Nilai $\Delta \mathrm{E} 2000$ lumut kerak setelah 48 jam perlakuan

Berdasarkan grafik 2 menunjukkan bahwa konsentrasi 3\% tidak menunjukkan adanya perubahan warna karena nilai $\Delta \mathrm{E} 2000<6$ sedangkan perubahan warna baru terjadi pada konsentrasi 5\%, 7\% dan 10\%. Semakin tinggi konsentrasi maka terjadi kenaikan nilai $\Delta \mathrm{E} 2000$, hal ini menandakan bahwa semakin besar konsentrasi terjadi perubahan warna. Konsentrasi emulsi sereh wangi 5\% sudah dapat merubah warna lumut kerak/lichen sesuai dengan pengamatan visual dan mikroskopis.

Konsentrasi optimum yang paling efektif untuk membunuh koloni lumut dan lumt kerak/lichen pada cagar budaya batu dan bata adalah emulsi serehw angi konsentrasi $10 \%$.

\section{Pengujian dampak penggunaan emulsi sereh wangi terhadap batu segar}

Pengujian dampak penggunaan emulsi sereh wangi terhadap batu segar dengan mengukur nilai LAB menggunakan alat kolorimeter, kemudian dihitung nilai $\Delta$ E2000 menggunakan software colortools untuk melihat perubahan warna. Emulsi sereh wangi konsentrasi $10 \%$ dipilih karena konsentrasi tertinggi yang digunakan dalam percobaan. Apabila emulsi sereh 
wangi konsentrasi $10 \%$ tidak berdampak merubah warna batuan maka hipotesa konsentrasi dibawah $10 \%$ juga tidak merubah warna batuan.

\begin{tabular}{|c|c|c|c|c|c|c|c|c|c|c|c|c|c|c|c|}
\hline \multicolumn{4}{|c|}{ Sebelum } & \multicolumn{3}{|c|}{ Hari 1} & \multicolumn{3}{|c|}{ Hari 2} & \multicolumn{3}{|c|}{ Hari 3} & \multicolumn{3}{|c|}{ Hari 6} \\
\hline No & $\mathrm{L}$ & A & $\mathrm{B}$ & $\mathrm{L}$ & A & $\mathrm{B}$ & L & A & $\mathrm{B}$ & L & A & B & L & A & B \\
\hline 1 & 44,5 & 0,2 & $\overline{0,6}$ & 39,1 & 0,7 & $\overline{0} \overline{1}$ & 39,4 & 1,3 & $\overline{0} \overline{1}$ & 39,9 & 0,8 & $\begin{array}{c}- \\
0,3\end{array}$ & 39,7 & 0,3 & 0,4 \\
\hline 2 & 42,9 & -1 & 1 & 38,6 & 0,8 & 0,8 & 38,6 & 0 & 1,5 & 39,4 & 0,5 & 1,2 & 38,6 & 0,3 & 0,7 \\
\hline 3 & 43,6 & 0,6 & $\begin{array}{c}0,3 \\
-\end{array}$ & 41,1 & 1,3 & $\begin{array}{c}0,4 \\
-\end{array}$ & 41,4 & 1,8 & $\begin{array}{c}0,3 \\
-\end{array}$ & 39,7 & 0,3 & $\begin{array}{c}0,4 \\
-\end{array}$ & 41,6 & 1,7 & $\begin{array}{c}1,2 \\
-\end{array}$ \\
\hline 4 & 45,5 & 0,7 & 0,6 & 42,1 & 2,2 & 1,2 & 42,7 & 1,8 & 0,6 & 42,1 & 1,3 & 0,6 & 43,1 & 1,4 & 0,8 \\
\hline 5 & 46,2 & 0 & $\begin{array}{c}0,2 \\
-\end{array}$ & 43,2 & 1 & 0,1 & 42,8 & 1,1 & 0,7 & 42,9 & 2,2 & $\begin{array}{c}1,3 \\
-\end{array}$ & 44,2 & 1 & 0,3 \\
\hline 6 & 46,7 & 0,7 & 0,8 & 42,8 & 1,1 & 0,7 & 40,9 & 0,5 & 1,1 & 43,9 & 1 & 0,2 & 43,3 & 1,1 & 0,6 \\
\hline 7 & 46,7 & 1,1 & 0,7 & 40,9 & 0 & 1 & 38,6 & 1,8 & 0,1 & 43,3 & 1,5 & 0 & 41,8 & 0,2 & 1,6 \\
\hline 8 & 46,1 & $\begin{array}{c}0,8 \\
-\end{array}$ & 0 & 39,2 & 0,8 & $\begin{array}{c}0,7 \\
-\end{array}$ & 42,5 & 1 & 0 & 41,9 & 0,1 & $\begin{array}{c}0,7 \\
-\end{array}$ & 40,1 & 2,3 & $\begin{array}{l}0 \\
-\end{array}$ \\
\hline 9 & 44,6 & 0,4 & $\begin{array}{c}0,7 \\
-\end{array}$ & 39,4 & 2,2 & $\begin{array}{c}0,7 \\
-\end{array}$ & 41,6 & 0,5 & $\begin{array}{l}0 \\
-\end{array}$ & 40,8 & 1,3 & $\begin{array}{c}0,3 \\
-\end{array}$ & 40,5 & 2,6 & $\begin{array}{r}1,7 \\
-\end{array}$ \\
\hline \multirow{3}{*}{$\begin{array}{c}10 \\
\text { Rata- } \\
\text { rata }\end{array}$} & 44,5 & 0,2 & 0,6 & 42,2 & 1,8 & 0,5 & 42,3 & 0,9 & 0,7 & 40,8 & 1,7 & 1,1 & 44 & 1,5 & $\begin{array}{c}0,1 \\
-\end{array}$ \\
\hline & 45,1 & 0,3 & 0,2 & 40,9 & 1,2 & 0,0 & 41,1 & 1,1 & 0,2 & 41,5 & 1,0 & 0,2 & 41,7 & 1,2 & 0,1 \\
\hline & \multicolumn{3}{|c|}{$\Delta E 2000$} & \multicolumn{3}{|c|}{4,1344} & \multicolumn{3}{|c|}{3,9146} & & \multicolumn{2}{|c|}{3,5171} & \multicolumn{2}{|c|}{3,4592} & \\
\hline
\end{tabular}

Untuk memperjelas nilai $\Delta \mathrm{E} 2000$, pada berbagai hari perlakuan emulsi sereh wangi maka disajikan dalam Grafik 3.

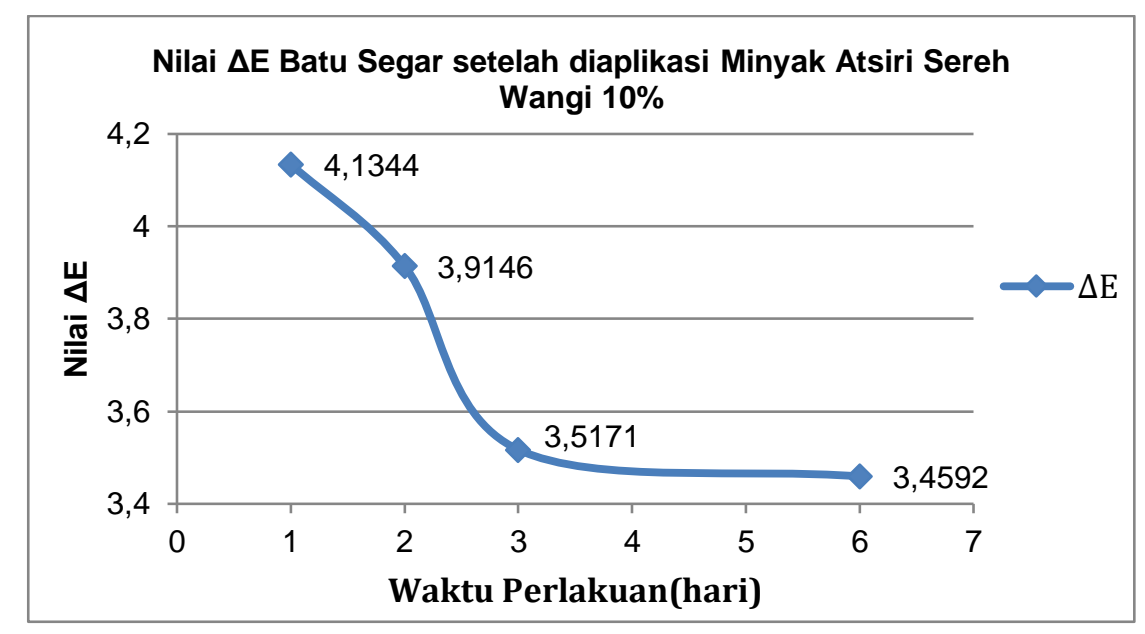

Grafik 3. Nilai $\Delta \mathrm{E} 2000$ batu segar setelah perlakuan

Berdasarkan grafik 3, nilai $\Delta \mathrm{E} 20001$ hari perlakuan, 2 hari perlakuan, 3 hari perlakuan dan 6 hari perlakuan, konsentrasi emulsi sereh wangi $10 \%$ menunjukkan tidak terjadi 
perbedaan warna pada batu segar, hal ini dari nilai $\Delta$ E2000 yang nilainya kurang dari 6 . Berdasarkan National Bureau of Standards GB7705-87 (National Institute of Standards and Technology), suatu benda dikatakan memiliki warna yang sama jika memiliki nilai $\Delta \mathrm{E}$ $\leq 6$. Sehingga dapat disimpulkan bahwa penggunaan emulsi sereh wangi tidak berdampak pada batuan dan tidak merubah warna batuan, sehingga secara arkeologis tidak merubah warna keaslian benda.

\section{Penerapan Emulsi Sereh Wangi Konsentrasi 10\% pada Cagar Budaya Batu dan Bata}

Penggunaan emulsi sereh wangi sudah digunakan untuk mengatasi pertumbuhan lumut dan lumut kerak/lichen pada cagar budaya berbahan batu dan bata.

Berikut ini beberapa contoh penggunaan bahan emulsi sereh wangi

a. Batu lepas Candi Borobudur

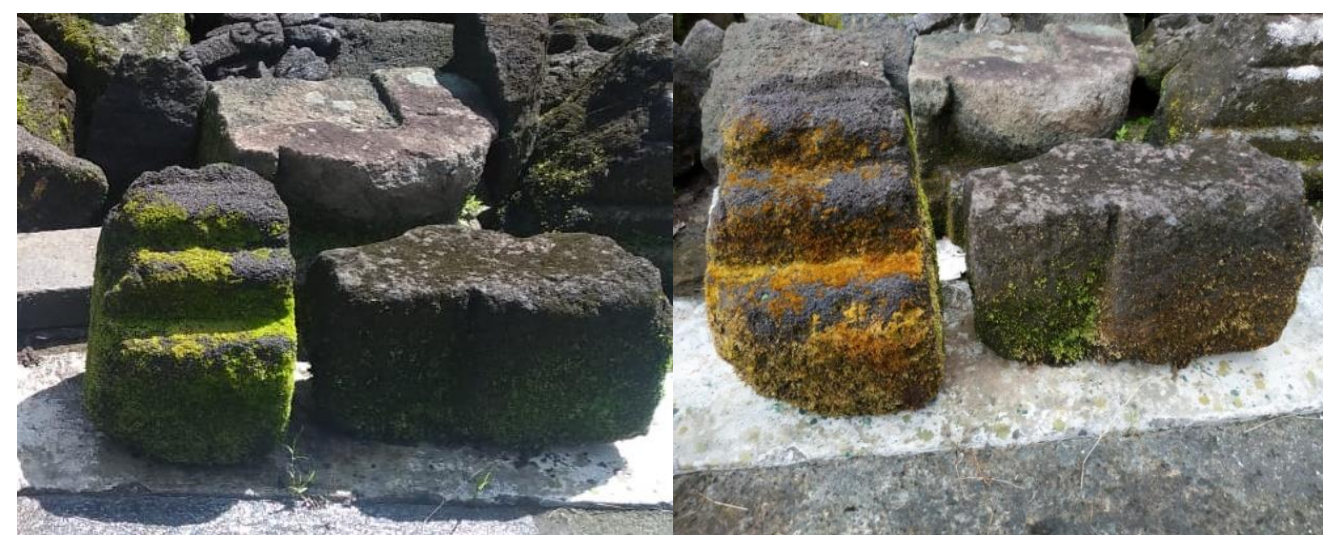

Gambar 6. Batu Lepas Candi Borobudur sebelum(kiri) dan setelah(kanan) pengaplikasian emulsi sereh wangi konsentrasi $10 \%$

(Sumber: Balai Konservasi Borobudur, 2021)

Pengaplikasian emulsi sereh wangi konsentrasi $10 \%$ dilakukan pada batu lepas Candi Borobudur yang berada di bunker tempat penyimpanan batu lepas bagian dari Candi Borobudur. Gambar 6 menunjukkan perubahan warna lumut dari hijau(kiri) menjadi kecoklatan(kanan) setelah pengaplikasian emulsi sereh wangi konsentrasi 10\% selama 24 jam pelakuan. Pengaplikasian emulsi sereh wangi dengan cara penyemprotan, tanpa dilakukan penutupan dengan plastik. 
b. Yoni Situs Plandi, Kawasan Cagar Budaya Borobudur

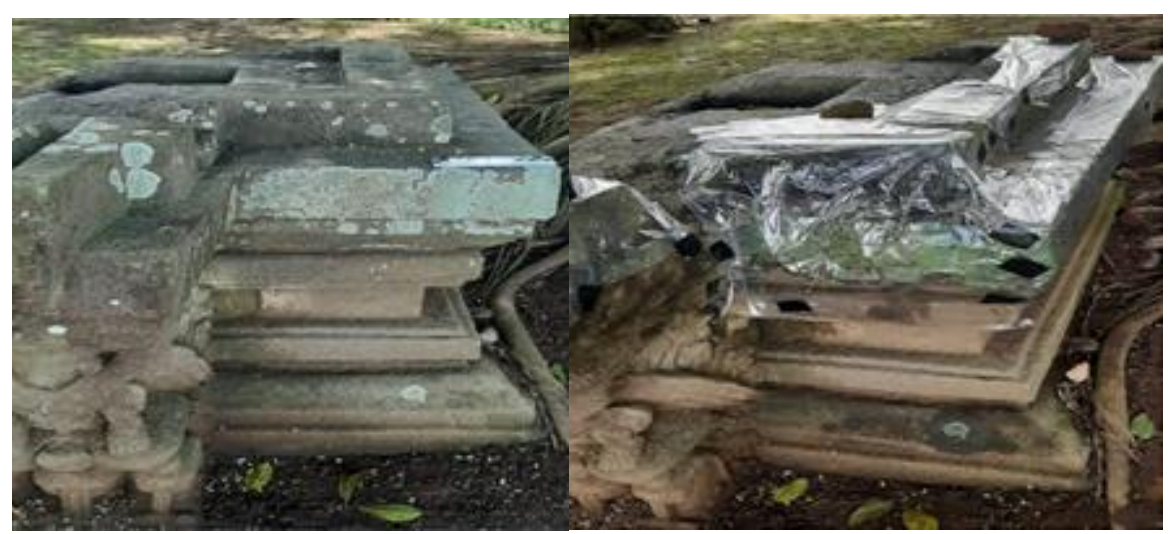

Gambar 7. Lichen pada batu Yoni Situs Plandi sebelum dan saat pengaplikasian emulsi sereh wangi konsentrasi $10 \%$ (Sumber: Dokumen Pribadi, 2021)

Penutupan plastik pada permukaan lumut kerak/lichen setelah penyemprotan emulsi sereh wangi bertujuan untuk mengurangi penguapan minyak atsiri sereh wangi sebagai bahan utama emulsi sereh wangi yang mempunyai sifat mudah menguap. Selain itu juga berfungsi untuk melindungi bahan uji dari hujan karena Yoni terletak di luar ruangan sehingga bahan uji masih tetap bereaksi.

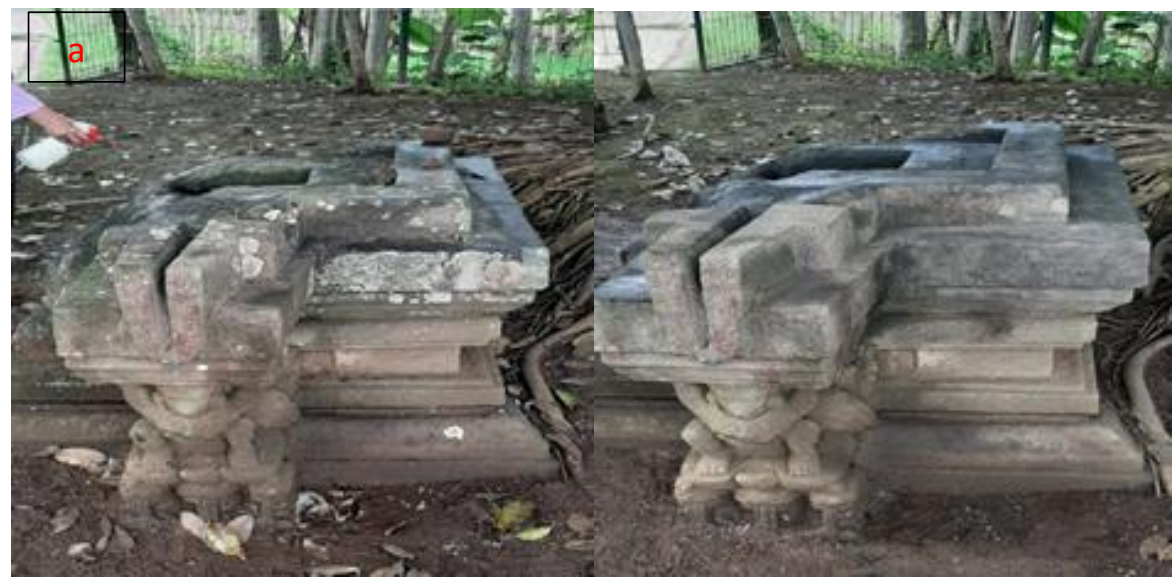

Gambar 7. Lichen sebelum(kiri) dan setelah(kanan) dibersihkan pasca pengaplikasian emulsi sereh wangi konsentrasi $10 \%$

(Sumber: Dokumen Pribadi, 2021)

Setelah lumut kerak/lichen berubah warna dari hijau menjadi coklat dan mengering langkah selanjutnya dilakukan pembersihan secara mekanis kering menggunakan sikat ijuk. 
c. Lumut pada Bata Situs Kalicilik, Kabupaten Blitar, Jawa Timur

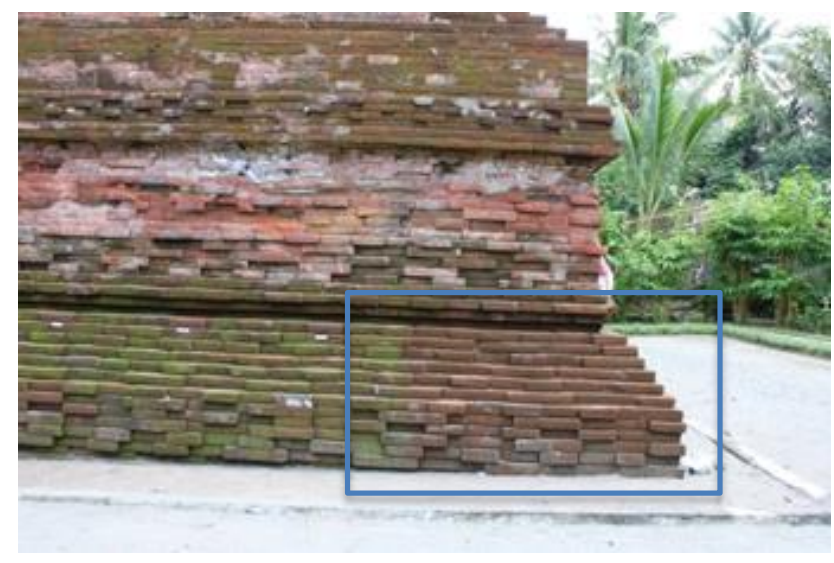

Gambar 8. Lumut sebelum(kiri) dan setelah(kanan) pengaplikasian emulsi sereh wangi konsentrasi $10 \%$

(Sumber: Dokumen Pribadi, 2021)

Pengaplikasian emulsi sereh wangi konsentrasi 10\% disemprotkan pada permukaan bata yang ditumbuhi lumut. Setelah penyemprotan terlihat pada Gambar 8 dalam kotak biru lumut sudah tidak nampak(tanpa pembersihan mekanis kering), menunjukkan bahwa lumut kering dan mati.

\section{KESIMPULAN}

1. Emulsi sereh wangi dapat digunakan sebagai bahan pengganti herbisida dalam mengatasi permasalahan lumut pada cagar budaya dan bahan pengganti AC 322 dalam mengatasi permasalahan lumut kerak/lichen pada cagar budaya

2. Emulsi sereh wangi konsentrasi $3 \%, 5 \%, 7 \%$ dan $10 \%$ dapat membunuh lumut durasi kontak 24 jam

3. Emulsi sereh wangi konsentrasi 5\%, 7\% dan 10\% dapat membunuh lumut kerak/lichen durasi kontak 48 jam

\section{SARAN / REKOMENDASI}

1. Emulsi sereh wangi konsentrasi maksimal $10 \%$ dapat digunakan untuk mengatasi permasalah lumut dan lumut kerak/lichen sekaligus mengantisispasi penguapan minyak atsiri sehingga emulsi dapat lebih maksimal bereaksi.

2. Pengaplikasian emulsi sereh wangi akan lebih maksimal apabila dilakukan waktu menjelang siang hari karena akan menganggu proses fotosintesis 
3. Pengaplikasian emulsi sereh wangi akan lebih maksimal apabila ditutup dengan plastik, hal ini bertujuan untuk mengurangi tingkat penguapan minyak atsiri dan menghindari tampias air hujan(apabila pengaplikasian bahan saat musim penghujan)

4. Perlu dilakukan penelitian lanjutan mengenai variasi surfaktan yang digunakan, surfaktan dalam bentuk pasta/gel sehingga minyak atsiri akan lebih lama bereaksi dengan lumut maupun lumut kerak/lichen

\section{DAFTAR PUSTAKA}

Altieri, A and Ricci, S. 1997. Calcium Uptake in Mosses and its Role in Stone Biodeterioration. Elsevier Science Limited. Vol. 40. No. 24 (1997) 20 I-204

Croci, Giorgio. 1989. The Conservationand structural Restoration of Architectural Heritage, Computational Mechanics Publication Southmpton, UK and Boston, USA.

De los Ríos, A., Ascaso, C., 2005. Contributions of in situ microscopy to the current understanding of stone biodeterioration. Int. Microbiol. 8, 181e188.

De los Ríos, A., Perez-Ortega, S., Wierzchos, J., Ascaso, C., 2012. Differential effects of biocide treatments on saxicolous communities: case study of the Segovia cathedral cloister (Spain). Int. Biodeterior. Biodegrad. 67, 64-72.

Hunterlab. 2008. Colorimeters versus spectrophotometers. Virginia : Technical Services Department Hunter Associates Laboratory.Inc

Kumar, Rakesh and Kumar, Anuradha. 1999. Biodeterioration of Stone in Tropical. Environments. The Getty Conservation Institute.

Ketaren, S. 1985. Pengantar Teknologi Miinyak Atsiri. Balai Pustaka, Jakarta

Prescott, L M, Harley JP, Klern D A. 1999. Microbiology $4^{h}$ ed. The MC Grow Hill, USA

Sastrohamidjojo, H. 2002. Kimia Minyak Atsiri. FMIPA Universitas Gadjah Mada. Yogyakarta

Wahyuni, Sri, dkk. 2015. Laporan Hasil Kajian Minyak Atsiri untuk Cagar Budaya Batu Tahap I. Balai Konservasi Borobudur

Wahyuni, Sri, dkk. 2016. Laporan Hasil Kajian Minyak Atsiri untuk Cagar Budaya Batu Tahap II. Balai Konservasi Borobudur 